\title{
The $\mathrm{SalGI}$ restriction endonuclease
}

\author{
Purification and properties \\ Anthony MAXWELL and Stephen E. HALFORD \\ Department of Biochemistry, University of Bristol, Bristol BS8 1TD, U.K.
}

(Received 9 September 1981/Accepted 8 December 1981)

\begin{abstract}
The type II restriction endonuclease SalGI has been purified to near homogeneity. At least $80 \%$ of the protein remaining after the final stage of the preparation is SalGI restriction endonuclease; no contaminating nucleases remain detectable. The principal form of the protein under both native and denaturing conditions is a monomer of $M_{\mathrm{r}}$ about 29000 . The optimal conditions for both enzyme stability and enzyme activity have been determined.
\end{abstract}

Type II restriction endonucleases are enzymes that specifically recognize short nucleotide sequences in double-stranded DNA and cleave the DNA at fixed locations relative to their recognition sites (Roberts, 1976). The first type II restriction endonuclease to be discovered was the HindII enzyme (Smith \& Wilcox, 1970); since then, over 200 enzymes of this type have been reported (Roberts, 1981). These enzymes have found wide application in the analysis and restructuring of DNA molecules and also provide convenient systems for studies on the interactions between proteins and specific sequences in nucleic acids since they require only $\mathrm{Mg}^{2+}$ as a cofactor (Roberts, 1976). Moreover, the recognition sites of many type II restriction enzymes possess an axis of two-fold rotational symmetry through the DNA, a factor common to many DNA-protein interactions (Jovin, 1976). However, studies of DNA-protein interactions require purified enzymes and only a few type II restriction endonucleases such as $E c o$ RI have been. obtained in pure form (Modrich, 1979).

SalGI is a type II restriction endonuclease isolated from Streptomyces albus G (Chater \& Wilde, 1976). This enzyme was originally designated SalI, but the discovery of a type II restriction endonuclease from S. albus P (Chater, 1977) has required that these enzymes be named SalGI and SalPI respectively (Chater \& Wilde, 1980). The

Abbreviations used: $\lambda$ TF DNA, the DNA from the bacteriophage $\lambda \mathrm{b} 221$ rex : $: \operatorname{tn} 5$, after digestion with $E c o R I$ restriction endonuclease as described in the Materials and methods section; SDS, sodium dodecyl sulphate.
SalGI restriction endonuclease (EC 3.1.23.37) recognizes double stranded DNA at the sequence:

$$
\begin{aligned}
& 5^{\prime}-{ }^{\downarrow}-T-C-G-A-C-3^{\prime} \\
& 3^{\prime}-C-A-G-C-T-G-5^{\prime}
\end{aligned}
$$

and cuts at the sites indicated by the arrows (Arrand et al., 1978). Genetic studies have demonstrated that this enzyme is part of a host-controlled restrictionmodification system (Chater \& Wilde, 1980). Halford et al. (1979) showed that the SalGI endonuclease may simultaneously cleave both strands of the DNA at its recognition site, in contrast with the EcoRI enzyme which cleaves each strand in a separate reaction. Hence these two enzymes appear to interact with DNA through different mechanisms. In this paper, we describe the purification of the SalGI restriction endonuclease and several properties of the enzyme. The following papers (Maxwell \& Halford, 1982a,b) describe studies on the mechanism of DNA cleavage by this enzyme and its specificity.

\section{Materials and methods}

\section{DNA preparations}

Bacteriophage $\lambda \mathrm{b} 221$ rex::tn5 (bacteriophage number $\lambda$ DB2523; Berg, 1977) was obtained from D. E. Berg (Washington University, St. Louis, MO, U.S.A.). The purification of this bacteriophage after infection of Escherichia coli $\mathrm{C}_{600}$ and the isolation of its DNA were as described previously (Halford $e t$ al., 1979). For use in enzyme assays, this DNA was digested with $E c o$ RI restriction endonuclease, ex- 
tracted twice with redistilled phenol, twice with chloroform and dialysed against $10 \mathrm{~mm}$-Tris $/ 0.1 \mathrm{mM}$ EDTA, pH 7.5; all reaction mixtures with DNA also contained $5 \mathrm{~mm}$-Tris $/ 0.05 \mathrm{~mm}$-EDTA in addition to the stated constituents. Supercoiled DNA from plasmid pMB9 was prepared as described previously (Halford \& Johnson, 1981) and that from plasmid pMB8 was a gift from Dr. S. J. Ford (this laboratory). The concentration of all DNA solutions were determined by absorbance with $A_{260}^{0.1 \%}=$ $20 \mathrm{~cm}^{-1}$ and are given in $\mu \mathrm{g} \cdot \mathrm{ml}^{-1}$. All DNA solutions were stored over chloroform at $4^{\circ} \mathrm{C}$.

\section{Purification of SalGI restriction endonuclease}

Growth of cells. S. albus $\mathrm{G}$ was grown on agar plates [Difco malt extract $\left(24 \mathrm{~g} \cdot 1^{-1}\right) /$ Oxoid yeast extract $\left(5 \mathrm{~g} \cdot 1^{-1}\right) /$ Difco bacto agar $\left(20 \mathrm{~g} \cdot 1^{-1}\right)$, $\mathrm{pH} 7.8$ ] at $30^{\circ} \mathrm{C}$ until sporulation occurred (about 4 days). Spores from one plate were resuspended in $10 \mathrm{ml}$ of sterile water, added to $10 \mathrm{ml}$ of sterile glycerol/water $(1: 1, \mathrm{v} / \mathrm{v})$ and stored at $-20^{\circ} \mathrm{C}$ for periods of up to 1 year. Each spore suspension was used to inoculate 1 litre of growth medium containing $8 \mathrm{~g}$ of Difco nutrient broth, $340 \mathrm{~g}$ of sucrose, $10 \mathrm{~g}$ of $\mathrm{MgCl}_{2}$ and $5 \mathrm{~g}$ of glucose, and the culture was shaken at $30^{\circ} \mathrm{C}$ for $48 \mathrm{~h}$. The enzyme preparation described below is from an 8 litre culture of $S$. albus G.

Harvesting and lysis. Cells were harvested by centrifugation $\left(15 \mathrm{~min}\right.$ at $\left.23000 \mathrm{~g}, 4^{\circ} \mathrm{C}\right)$ and cell pellets were washed with $0.2 \mathrm{M}-\mathrm{NaCl}$ in enzyme buffer $\left(10 \mathrm{mM}-\mathrm{K}_{2} \mathrm{HPO}_{4} / 10 \mathrm{mM}-\beta\right.$-mercaptoethanol/ $1 \mathrm{~mm}$-EDTA, pH 8.0). (Cell pellets at this stage could be stored for several weeks at $-20^{\circ} \mathrm{C}$.) Pellets were resuspended in $500 \mathrm{ml}$ of $0.2 \mathrm{M}-\mathrm{NaCl}$ in enzyme buffer and $2.5 \mathrm{~g}$ of lysozyme was added. After $30 \mathrm{~min}$ at $37^{\circ} \mathrm{C}$, the suspension was cooled to $4^{\circ} \mathrm{C}$. (All further stages in the procedure were conducted at $4^{\circ} \mathrm{C}$.) This suspension was then disrupted by sonication in small batches. Cell debris was removed by centrifugation $(30 \mathrm{~min}$ at $100000 \mathrm{~g}$ ) and the supernatant was retained.

Phosphocellulose chromatography. The $100000_{\mathrm{g}}$ supernatant was applied to a $150 \mathrm{ml}$ phosphocellulose column (Whatman P11, Whatman, Maidstone, Kent, U.K.) prepared as described by Greene et al. (1978) and equilibrated in $0.2 \mathrm{M}-\mathrm{NaCl}$ in enzyme buffer. The column was washed with the same buffer until the $A_{280}$ of the eluant fell to zero; the eluant was monitored for $A_{280}$ with an Isco UA-5 (MSE Scientific Instruments, Crawley, Sussex, U.K.). The column was developed with $0.75 \mathrm{M}-\mathrm{NaCl}$ in enzyme buffer and the eluant was collected across the single peak of $A_{280}$-absorbing material. The peak was immediately dialysed against $50 \mathrm{mM}-\mathrm{NaCl}$ in enzyme buffer. After dialysis, the resulting precipitate was removed by centrifugation $(10 \mathrm{~min}$ at $38000 \mathrm{~g}$ ).
DEAE-Sephadex chromatography. The supernatant was applied to a $65 \mathrm{ml}$ DEAE-Sephadex column (Sephadex A-50, Pharmacia Fine Chemicals, Uppsala, Sweden), equilibrated in $50 \mathrm{~mm}-\mathrm{NaCl}$ in enzyme buffer. The column was washed with the same buffer and the eluant was monitored to zero $A_{280}$ as before. The column was developed with a linear gradient $(300 \mathrm{ml})$ of $0.05-0.6 \mathrm{M}-\mathrm{NaCl}$ in enzyme buffer. Fractions were collected and assayed for SalGI endonuclease. Fractions containing the peak of enzyme activity $(0.2-0.3 \mathrm{M}-\mathrm{NaCl})$ were pooled and dialysed against $0.1 \mathrm{M}-\mathrm{NaCl}$ in enzyme buffer.

Heparin-agarose chromatography. The DEAESephadex pool was applied to a $4 \mathrm{ml}$ heparinagarose column (Heparin-Sepharose CL-6B, Pharmacia), equilibrated in $0.1 \mathrm{M}-\mathrm{NaCl}$ in enzyme buffer. The column was washed in the same buffer, developed with a linear gradient $(40 \mathrm{ml})$ of $0.1-1.0 \mathrm{M}$ $\mathrm{NaCl}$ in enzyme buffer and fractions were collected. After assaying, peak fractions $(0.45-0.55 \mathrm{M}-\mathrm{NaCl})$ were pooled and dialysed against $0.1 \mathrm{M}-\mathrm{NaCl}$ in enzyme buffer.

Hydroxyapatite chromatography. The heparinagarose pool was applied to a $0.5 \mathrm{ml}$ hydroxyapatite column (Bio-Gel HTP, from Bio-Rad Laboratories, Richmond, CA, U.S.A.) equilibrated in $0.1 \mathrm{M}-\mathrm{NaCl}$ in enzyme buffer. The column was washed in the same buffer and the eluant was monitored as before. The column was developed with a linear gradient $(6 \mathrm{ml})$ of $0.01-0.3 \mathrm{M}-\mathrm{K}_{2} \mathrm{HPO}_{4}$ in $10 \mathrm{mM}-\beta$-mercaptoethanol/1 mM-EDTA/0.1 M-NaCl, pH 8.0. After assaying, peak fractions $\left(0.12-0.17 \mathrm{M}-\mathrm{K}_{2} \mathrm{HPO}_{4}\right)$ were dialysed against $0.2 \mathrm{M}-\mathrm{NaCl} / 50 \%$ (v/v) glycerol in enzyme buffer. Enzyme preparations were stored at $-20^{\circ} \mathrm{C}$ in this buffer.

\section{Assay of SalGI restriction endonuclease}

Wild type bacteriophage $\lambda$ DNA possesses two SalGI recognition sites, both near the centre of the molecule (Chater \& Wilde, 1976), and the products obtained by cleavage at these sites cannot readily be resolved from intact substrate by electrophoresis. DNA from the bacteriophage $\lambda \mathrm{b} 221$ rex:: $\operatorname{tn} 5$ carries an extra SalGI site within the tn5 element and its cleavage by the SalGI enzyme yields a DNA band of higher electrophoretic mobility, which can easily be resolved from intact substrate. By using EcoRI fragments of this DNA ( $\lambda T F$ ) as a substrate for the SalGI restriction endonuclease, partial products formed after the cleavage of the DNA at some but not all SalGI sites can be observed. Hence an estimate of the SalGI activity can be made from the time taken to reach the reaction end-point with the complete disappearance of partial products (Fig. 1). For qualitative assays, $1-5 \mu 1$ of enzyme were incubated with $0.5 \mu \mathrm{g}$ of $\lambda \mathrm{TF}$ DNA in assay buffer ( $50 \mathrm{~mm}$-Tris/ $10 \mathrm{mM}-\mathrm{MgCl}_{2} / 125 \mathrm{mM}-\mathrm{NaCl} / 10 \mathrm{mM}-\beta$ - 
mercaptoethanol $/ 0.5 \mathrm{mg} \cdot \mathrm{ml}^{-1}$ bovine serum albumin) in a total volume of $20 \mu \mathrm{l}$, at $37^{\circ} \mathrm{C}$. Digestion was stopped by the addition of $10 \mu \mathrm{l}$ of stop mix [40\% (w/v) sucrose/0.1 M-Tris/0.1 M-EDTA/ $0.5 \mathrm{mg} \cdot \mathrm{ml}^{-1}$ Bromophenol Blue, pH8.0]. After incubation at $67^{\circ} \mathrm{C}$ for $10 \mathrm{~min}$ and quenching on ice, samples were analysed by electrophoresis through $0.67 \%$ agarose slab gels (Sharp et al., 1973) at $9 \mathrm{~V} \cdot \mathrm{cm}^{-1}$ for $1 \mathrm{~h}$. Quantitative assays were performed by withdrawing samples $(15-20 \mu \mathrm{l})$ at timed intervals from $100 \mu \mathrm{l}$ reaction mixtures containing $2.5 \mu \mathrm{g}$ of $\lambda \mathrm{TF}$ DNA and SalGI enzyme in assay buffer at $37^{\circ} \mathrm{C}$. Each sample was immediately added to $10 \mu \mathrm{l}$ of stop mix and analysed as before (Fig. 1). One unit of SalGI restriction endonuclease was taken as the amount of enzyme required to completely digest $0.5 \mu \mathrm{g}$ of $\lambda$ TF DNA in $20 \mu$ l of assay buffer in $1 \mathrm{~h}$ at $37^{\circ} \mathrm{C}$.

\section{Other materials and methods}

Restriction endonuclease EcoRI and $E$. coli alkaline phosphatase were prepared as described previously (Halford, 1971; Halford et al., 1979). DNA ligase of phage $T_{4}$ was a gift from Dr. A. G.

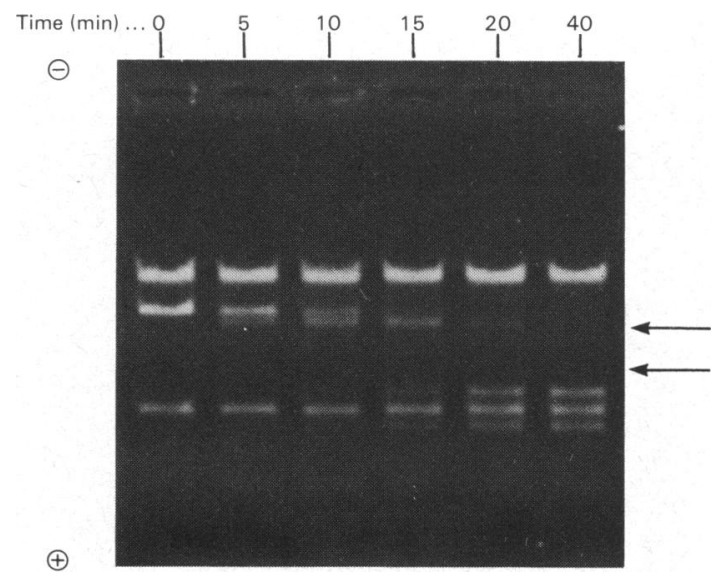

Fig. 1. Assay of SalGI restriction endonuclease Samples $(15 \mu l)$ were withdrawn, at timed intervals after the addition of enzyme, from $100 \mu$ l containing $2.5 \mu \mathrm{g}$ of $\lambda$ TF DNA and 10 units of SalGI enzyme in $50 \mathrm{~mm}$-Tris $/ 10 \mathrm{~mm}-\mathrm{MgCl}_{2} / 125 \mathrm{~mm}-\mathrm{NaCl} / 10 \mathrm{~mm}$ $\beta$-mercaptoethanol $/ 0.5 \mathrm{mg} \cdot \mathrm{ml}^{-1}$ bovine serum albumin, $\mathrm{pH} 8.0$, at $37^{\circ} \mathrm{C}$. Samples were immediately added to $10 \mu \mathrm{l}$ of stop mix and analysed by gel electrophoresis; the gel is shown above. The time of withdrawal (in min) of each sample is noted by each track on the gel; the zero-time point was taken before the addition of enzyme. The polarity of the gel is marked on the left-hand side and the positions of partial digestion products are marked by arrows on the right hand side.
Hepburn (John Innes Institute, Norwich, U.K.). Hen ovalbumin and human type $C$ transferrin were gifts from Dr. J. Williams (this department). Horse heart myoglobin, bovine erythrocyte carbonic anhydrase and bovine serum albumin were obtained from Sigma. Protein concentrations were determined by the method of Bradford (1976) using EcoRI restriction endonuclease as the standard. Solutions containing bovine serum albumin were heated at $67^{\circ} \mathrm{C}$ for $2 \mathrm{~h}$ before use in assays in order to inactivate contaminating nucleases.

\section{Results and discussion}

\section{Purification of restriction endonuclease SalGI}

Previous preparations of the SalGI restriction endonuclease have only separated the enzyme from contaminating nucleases (Chater \& Wilde, 1976; Arrand et al., 1978; Greene et al., 1978). The procedure described in the Materials and methods section yields SalGI restriction enzyme of greater than $80 \%$ homogeneity (as shown below), with higher yields of enzyme per litre of bacterial culture

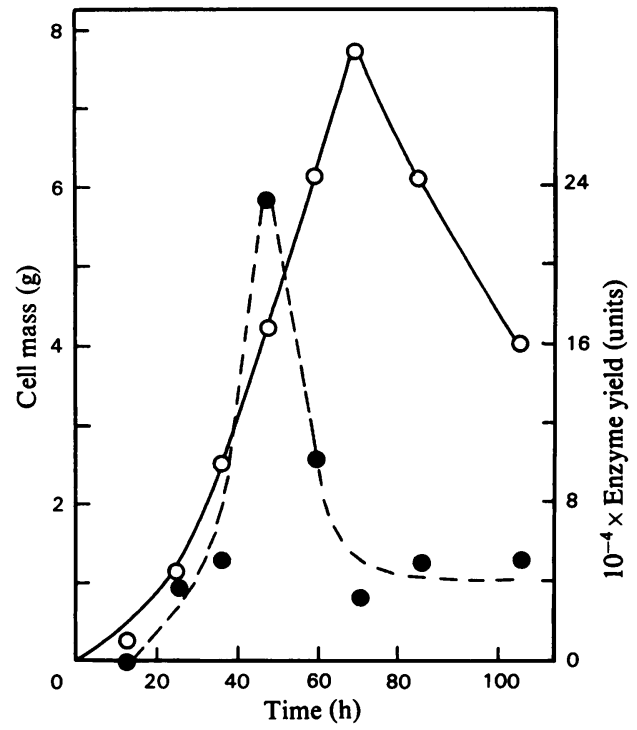

Fig. 2. Growth of Streptomyces albus $G$ The cell mass (O) and yield of SalGI restriction endonuclease (O) were determined from $100 \mathrm{ml}$ samples taken at timed intervals from a 1 litre culture of $S$. albus $\mathbf{G}$ inoculated at time zero and shaken at $30^{\circ} \mathrm{C}$. Left-hand ordinate: cell mass was determined by weighing the washed pellet after centrifugation at $23000 \mathrm{~g}$. Right-hand ordinate: enzyme yields were determined by following the preparative procedure, as described in the Materials and methods section, to the $100000 \mathrm{~g}$ supernatant stage for each sample and assaying for $\mathrm{SalGI}$ restriction endonuclease. 
than had previously been described. We have found that the time of harvesting $S$. albus cultures affects the yield of enzyme; the peak of production of SalGI enzyme occurs during the exponential phase of growth (Fig. 2). Growth of the bacteria at $30^{\circ} \mathrm{C}$ produced a high yield of enzyme whereas at $37^{\circ} \mathrm{C}$ very little enzyme was obtained. As discussed below, restriction endonuclease $S a l G I$ is more unstable under certain conditions of $\mathrm{pH}$ and ionic strength than under other conditions, so we employ a $\mathrm{pH}$ of 8.0 and minimize the exposure of the enzyme to high salt concentrations $(>0.35 \mathrm{M})$ in order to favour enzyme stability. Moreover, as enzyme activity is lost with time even under optimal conditions, we minimize the time taken for each stage; the procedure is routinely completed within 4 days.

The use of phosphocellulose in the preparation of the SalGI restriction enzyme has been described previously (Greene et al., 1978). This step gives a large purification because the vast majority of the material applied to this column (as judged by $A_{280}$ ) does not bind to the resin. We have replaced elution by a $\mathrm{NaCl}$ gradient (Greene et al.. 1978) by a single step elution with $0.75 \mathrm{M}-\mathrm{NaCl}$ followed immediately by dialysis against $50 \mathrm{~mm}-\mathrm{NaCl}$. This eliminates lengthy exposure to high salt without reducing the purification. In our preparation, we have replaced DEAE-cellulose (Arrand et al., 1978) with DEAESephadex as this permits faster flow rates. Again the vast majority of the material applied to this column does not bind to the resin and an $\mathrm{NaCl}$ gradient resolves the SalGI enzyme from many other proteins. SDS/polyacrylamide electrophoresis of the pooled fractions from the DEAE-Sephadex column revealed about 10 bands of separate proteins, in contrast with more than 50 bands remaining after the phosphocellulose column. However, we experience large losses in enzyme activity at this stage (Table 1), probably due to the time taken to run this column and to assay the column fractions. Heparinagarose has been widely used in restriction enzyme preparations, including the partial purification of SalGI (Chater \& Wilde, 1980). Although a proportion of the proteins in the DEAE-Sephadex pool bind to heparin-agarose, an $\mathrm{NaCl}$ gradient elutes most of these in advance of the SalGI enzyme. SDS/ polyacrylamide-gel electrophoresis showed the heparin-agarose pool to contain four bands, of which SalGI enzyme constituted the major component. The minor contaminants from the heparinagarose pool were removed on hydroxyapatite.

Our procedure yields a single major band of protein upon SDS/polyacrylamide-gel electrophoresis by the method of Laemmli (1970). This band was shown by densitometry to account for at least $80 \%$ of the total protein (Fig. 3). Analysis by polyacrylamide-gel electrophoresis under native conditions (Davis, 1964) again showed only one major band after staining for protein (results not shown). An identical sample on this gel was cut into $3 \mathrm{~mm}$ slices and the protein was eluted from each slice by incubating in $0.2 \mathrm{M}-\mathrm{NaCl}$ in enzyme buffer. The eluant from each slice was assayed for SalGI restriction enzyme; the peak of activity was comigrant with the major band in the stained sample.

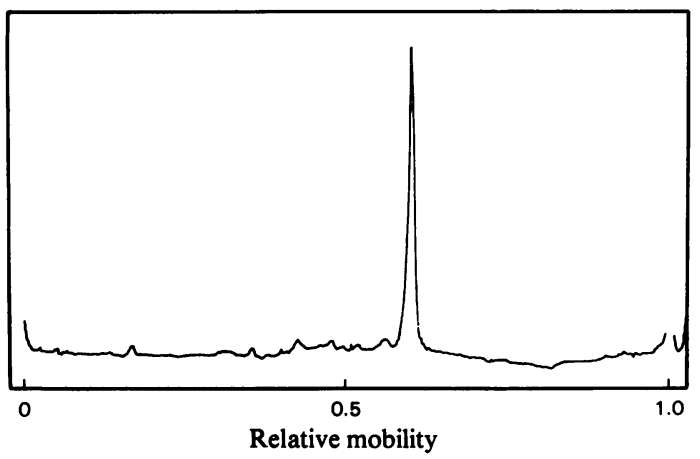

Fig. 3. Purity of SalGI restriction endonuclease A sample of purified SalGI restriction endonuclease (16000 units) was denatured in 2\% SDS by boiling and subjected to electrophoresis through a $15 \%$ polyacrylamide slab gel containing $0.1 \%$ SDS, as described by Laemmli (1970). After staining for protein, the gel track containing the SalGI enzyme was analysed by densitometry; the densitometric trace is shown above. Electrophoretic mobilities are expressed relative to the mobility of Bromophenol Blue; zero denotes the gel boundary.

Table 1. Purification of SalGI restriction endonuclease

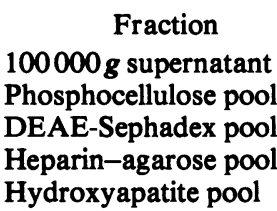

Fraction

$100000 \mathrm{~g}$ supernatant Phosphocellulose pool DEAE-Sephadex pool Hydroxyapatite pool

Total protein (mg)
1800
450
4.1
0.4
0.15

$10^{-6} \times$ Total enzyme
activity (units)
50
30
3
1
0.4

$10^{-4} \times$ Specific activity (units $\cdot \mathrm{mg}^{-1}$ ) 

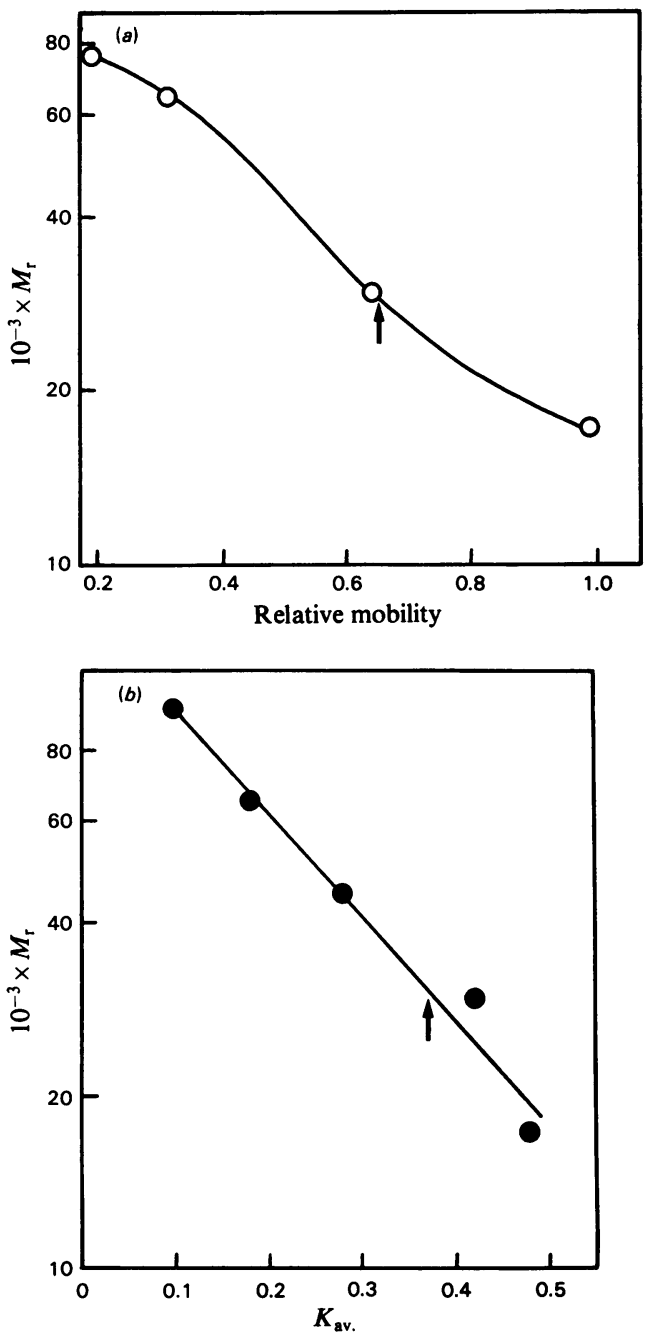

Fig. 4. Molecular weight of SalGI restriction endonuclease

(a) Electrophoresis of purified SalGI restriction endonuclease and proteins of known molecular weight on an SDS/polyacrylamide-gel was as described in the legend to Fig. 3. Molecular weight standards were; human transferrin (78000), bovine serum albumin (65000), carbonic anhydrase (29500) and myoglobin (17200): (0) indicates the relative mobility of molecular weight standards. The vertical arrow indicates the relative mobility of SalGI restriction endonuclease. Relative mobilities were calculated as the mobility of a protein band compared with the mobility of Bromophenol Blue. (b) Gel filtration of purified SalGI restriction endonuclease and proteins of known molecular weights was carried out using a Sephacryl S-200 column $\left(90 \mathrm{~cm} \times 1.4 \mathrm{~cm}^{2}\right)$ with elution by $0.2 \mathrm{M}$ $\mathrm{NaCl}$ in enzyme buffer. Elution volumes for standard proteins were determined by $A_{280}$ and the elution volume for the SalGI enzyme was determined by assaying column fractions. The $K_{\mathrm{av} \text {. }}$ for standard
Hence the major protein in this preparation is SalGI restriction endonuclease.

Although the enzyme has been 12000-fold purified in terms of protein (Table 1), a large loss in enzyme activity is experienced during the procedure due to the extreme instability of the enzyme under certain conditions. It is therefore possible that the purified protein contains both active and denatured forms of the enzyme. However, the final specific activity $\left(3 \times 10^{6}\right.$ units $\left.\cdot \mathrm{mg}^{-1}\right)$ is similar to those reported for other restriction endonucleases, such as BstI, $6 \times 10^{5}$ units $\cdot \mathrm{mg}^{-1}$ (Clarke \& Hartley, 1979) and EcoRI, $1 \times 10^{7}$ units $\cdot \mathrm{mg}^{-1}$ (Halford et al., 1979); for each of these enzymes, slightly different definitions for units of enzyme activity were used. Because of their utility in genetic engineering, it is desirable that high yields should be achieved in the purification of restriction enzymes. One strategy to enhance yields has been the cloning of the genes coding for restriction enzymes (Smith, 1979). Our studies on the preparation of SalGI have shown that the yield of one restriction endonuclease can be improved by manipulating existing procedures without the necessity for cloning. It is probable that improvements in the yields of other restriction endonucleases could be made in a similar way.

\section{Molecular weight studies}

SDS/polyacrylamide electrophoresis of purified SalGI restriction endonuclease gave an apparent subunit $M_{\mathrm{r}}$ of 29000 for the enzyme (Fig. 4a). To determine the $M_{\mathrm{r}}$ under native conditions, gelfiltration studies were performed under two sets of conditions by the method of Andrews (1965). Elution with enzyme buffer containing $0.2 \mathrm{M}-\mathrm{NaCl}$ gave a single peak of enzyme activity corresponding to an $M_{\mathrm{r}}$ of about 30000 (Fig. $4 b$ ). However, elution with assay buffer gave both a predominant peak of activity corresponding to an $M_{\mathrm{r}}$ of 30000 and also a broad peak of low activity corresponding to a range of $M_{\mathrm{r}}$ values from 50000 to 120000 . It is therefore possible that, under assay conditions, the enzyme exists in an equilibrium between monomer and aggregated states. Maxwell \& Halford (1982a) suggest that the active form of the enzyme is a dimer. Several other restriction endonucleases are active in the dimeric form; for example, EcoRI and BamHI (Modrich, 1979). Clarke \& Hartley (1979) have shown that the BstI restriction enzyme behaves

proteins are shown by (O) and the vertical arrow indicates the $K_{\text {av. }}$ for the SalGI enzyme. Molecular weight standards were: alkaline phosphatase (94000), bovine serum albumin (65000), ovalbumin (45000), carbonic anhydrase (29500) and myoglobin (17200). $K_{\text {av. }}$ is defined by $K_{\text {av. }}=\left(V_{\mathrm{e}}-V_{\mathrm{o}}\right) /$ $\left(V_{\mathrm{t}}-V_{\mathrm{o}}\right)$, where $V_{\mathrm{e}}$ is the elution volume of the sample, $V_{0}$ the void volume of the column and $V_{\mathrm{t}}$ the total column volume. 
as a monomer during gel filtration under one set of conditions but as a dimer under other conditions. They suggest that the active form of the enzyme is a dimer but that the association between subunits is weak. It is possible that a similar phenomenom occurs with the SalGI restriction endonuclease.

\section{Specificity of DNA cleavage}

Many applications of restriction endonucleases do not require that the enzymes be pure. In most cases, it is sufficient that the activities of contaminating nucleases are minimal so that DNA cleavage occurs exclusively at the recognition site for the restriction enzyme. We have used sensitive assays to detect contamination by either non-specific endonucleases or exonucleases at each stage of the enzyme preparation.

Endonucleases can be readily observed by the conversion of supercoiled DNA into either its open-circle form, following a single strand cleavage at any site on the DNA or into its linear form, where both strands of the DNA have been cleaved at the same site. Supercoiled, open-circle and linear forms of many DNA molecules may be separated by electrophoresis through agarose (Johnson \& Grossman, 1977). The DNA from the related plasmids, pMB8 and pMB9 (Rodriguez et al., 1976), can both be prepared in the supercoiled form; pMB9 has a single SalGI recognition site but pMB8 has no SalGI site. Thus, comparisons of the cleavage of these two DNA molecules by preparations of the SalGI enzyme give a measure of the level of the contamination by non-specific endonucleases at each stage of the enzyme purification (Table 2a). For experiments where the presence of non-specific endonucleases is undesirable, such as the mapping of DNA molecules, SalGI restriction endonuclease prepared to the DEAE-Sephadex stage would be of sufficient purity.

Restriction endonuclease SalGI cleaves DNA at its recognition site to yield complementary $5^{\prime}$ single stranded extensions of four bases (Arrand et al., 1978) which can be re-annealed to generate novel DNA molecules. Contaminating exonucleases would remove these single stranded extensions and prevent reannealing. Hence the efficiency with which DNA molecules, cleaved by the SalGI enzyme, may be re-ligated by DNA ligase gives an indication of the activity of contaminating exonucleases (Table $2 b$ ). However, if the exonuclease removes one or more bases of the single strand extensions, it is still possible that the DNA molecules may be re-ligated. But such molecules would no longer be substrates for the SalGI endonuclease as they lack the correct recognition sequence. Thus the complete cleavage of re-ligated DNA molecules by the SalGI enzyme demonstrates that the single strand extensions have remained intact (Table $2 c$ ). For experiments involving the re-annealing of DNA fragments that were obtained by cleavage with the SalGI endonuclease

Table 2. Specificity of DNA cleavage by restriction endonuclease SalGI

(a) Values refer to the ratio of the minimum amount of SalGI enzyme required to cleave $1 \mu \mathrm{g}$ of plasmid pMB8 DNA over the minimum amount required to cleave $1 \mu \mathrm{g}$ of plasmid pMB9 DNA in $20 \mu \mathrm{l}$ of $50 \mathrm{mM}-\mathrm{Tris} / 10 \mathrm{mM}-\mathrm{MgCl}_{2} /$ $125 \mathrm{~mm}-\mathrm{NaCl} / 10 \mathrm{mM}-\beta$-mercaptoethanol $/ 0.5 \mathrm{mg} \cdot \mathrm{ml}^{-1}$ bovine serum albumin, $\mathrm{pH} 8.0$, in $1 \mathrm{~h}$ at $37^{\circ} \mathrm{C}$. Values for the last three stages of the preparation are lower limits as no digestion of plasmid pMB8 could be observed at the maximum enzyme concentration. (b) Plasmid pMB9 DNA ( ${ }^{3} \mathrm{H}$-labelled, $\left.1 \mu \mathrm{g}\right)$ in $40 \mu \mathrm{l}$ of $50 \mathrm{mM}-\mathrm{Tris} / 10 \mathrm{mM}-\mathrm{MgCl}_{2} /$ $125 \mathrm{mM}-\mathrm{NaCl} / 10 \mathrm{mM}-\beta$-mercaptoethanol $/ 0.5 \mathrm{mg} \cdot \mathrm{ml}^{-1}$ bovine serum albumin, $\mathrm{pH} 8.0$, was digested for $1 \mathrm{~h}$ at $37^{\circ} \mathrm{C}$ with 10-fold excesses of SalGI enzyme from each stage of the preparation. After cooling on ice, the same amount of T4 DNA ligase was added to each sample and each was made $0.1 \mathrm{~mm}$ in ATP. Samples, at $16^{\circ} \mathrm{C}$, were then allowed to cool to $0^{\circ} \mathrm{C}$ over several hours. A $20 \mu \mathrm{l}$ aliquot was removed from each, added to $10 \mu \mathrm{l}$ of stop mix and subjected to electrophoresis on a $1 \%$ agarose gel at $5 \mathrm{~V} \cdot \mathrm{cm}^{-1}$. Linear DNA was separated from re-ligated forms and the proportions of each was estimated by scintillation counting (Halford et al., 1979). Values represent the proportions of re-ligated species in each sample, corrected for the efficiency of the DNA ligase preparation used (55\% under these conditions). (c) To the remainder of each sample in (b), 10 units of SalGI enzyme were added and each was incubated at $37^{\circ} \mathrm{C}$ for $30 \mathrm{~min}$. The products were analysed by electrophoresis and scintillation counting as above. Values represent the percentage of the re-ligated forms in $(b)$ which were cleaved by the SalGI enzyme.
(a) Amount of enzyme to cleave pMB8 DNA over amount required to

Fraction

$100000 \mathrm{~g}$ supernatant Phosphocellulose pool DEAE-Sephadex pool Heparin-agarose pool Hydroxyapatite pool
Re-ligation and re-cleavage efficiencies of pMB9 DNA digested with 10-fold excess of SalGI enzyme

$\begin{array}{cc}\text { (b) Re-ligation (\%) } & \text { (c) Re-cleavage (\%) } \\ 8 & 17 \\ 20 & 12 \\ 37 & 19 \\ 90 & 85 \\ 100 & 85\end{array}$


or for DNA sequencing, preparation of the SalGI enzyme to the heparin-agarose stage would be of sufficient purity.

\section{Enzyme stability and activity}

As mentioned above, the SalGI restriction endonuclease is unstable under certain buffer conditions. The optimal conditions for enzyme stability have been determined by storing the enzyme in a variety of buffers at $4^{\circ} \mathrm{C}$ and assaying the restriction endonuclease after periods varying from a few hours to several weeks. The optimal $\mathrm{pH}$ for enzyme stability is pH 8.0; storage below $\mathrm{pH} 7.0$ or above pH 9.0 leads to major losses in activity (75\% over 2 weeks). The optimal $\mathrm{NaCl}$ concentration for enzyme stability is in the range $0.05-0.35 \mathrm{M}-\mathrm{NaCl}$. Enzyme stored for 3 days with no $\mathrm{NaCl}$ lost $40 \%$ of its original activity whilst enzyme stored with $0.5 \mathrm{M}$ $\mathrm{NaCl}$ lost over $90 \%$. In addition, total protein concentration affects the stability of the enzyme. If the concentration of purified enzyme was less than $1 \times 10^{5}$ units $\cdot \mathrm{ml}^{-1}$, then bovine serum albumin $\left(0.5 \mathrm{mg} \cdot \mathrm{ml}^{-1}\right)$ was required to maintain enzyme stability. We find that the SalGI restriction endonuclease may be stored in $10 \mathrm{mM}-\mathrm{KH}_{2} \mathrm{PO}_{4} / 10 \mathrm{mM}$ $\beta$-mercaptoethanol $/ 0.2 \mathrm{M}-\mathrm{NaCl} / 1 \mathrm{mM}$-EDTA $/ 50 \%$ (v/v) glycerol $/ 0.5 \mathrm{mg} \cdot \mathrm{ml}^{-1}$ bovine serum albumin, $\mathrm{pH} 8.0$, at $-20^{\circ} \mathrm{C}$ for longer than 18 months without loss of enzyme activity.

The optimal reaction conditions for SalGI restriction endonuclease activity were determined by assaying the enzyme with $\lambda$ TF DNA, as in Fig. 1, but under a range of buffers. The optimal conditions were found to be $50 \mathrm{mM}$-Tris $/ 10 \mathrm{mM}-\mathrm{MgCl}_{2} / 125 \mathrm{mM}$ $\mathrm{NaCl} / 10 \mathrm{~mm}-\beta$-mercaptoethanol $/ 0.5 \mathrm{mg} \cdot \mathrm{ml}^{-1}$ bovine serum albumin, $\mathrm{pH} 8.0$; alterations from these values to the concentrations of either $\mathrm{NaCl}$ or $\mathrm{MgCl}_{2}$, or to the $\mathrm{pH}$, caused a reduction in the rate of DNA cleavage. However, the cleavage of $\lambda$ TF DNA measures only the formation of products cleaved in both strands of the DNA at the recognition site, whereas products cleaved in one strand only remain undetected. Maxwell \& Halford (1982a) report that alterations to the $\mathrm{pH}$ or reductions in the $\mathrm{MgCl}_{2}$ concentrations caused not only a decrease in the overall rates of the reactions but also the formation of products cleaved in only one strand of the DNA. Changes to the ionic strength of the reaction mixtures did not alter the nature of the reaction products but only reduced the overall rate; slow rates observed at concentrations of $\mathrm{MgCl}_{2}$ above $10 \mathrm{~mm}$ were found to be due to a general ionic strength effect.

The effect of other divalent cations on the cleavage of DNA by SalGI restriction endonuclease has been investigated. Manganese can replace magnesium although the overall rate of DNA cleavage is slower. A very slow rate is obtained with cobalt but neither zinc nor calcium will support the reaction of the SalGI enzyme. Low concentrations $(1 \mathrm{mM})$ of $p$-chloromercuribenzoate and mercuric chloride completely inactivate the SalGI restriction endonuclease, indicating that thiol groups may be involved in maintaining enzyme activity; $\beta$-mercaptoethanol is included in all buffers to counteract the possible effects of such agents. As found in studies of enzyme stability, the addition of bovine serum albumin $\left(0.5 \mathrm{mg} \cdot \mathrm{ml}^{-1}\right)$ to reaction mixtures is required to maintain enzyme activity at high dilutions. Arrand et al. (1978) and Bingham \& Atkinson (1978) have reported the appearance of two other restriction endonucleases (designated SalII and SalIII) during preparations of the SalGI enzyme from $S$. albus G. We have not observed these activities during our preparations.

We thank Dr. J. Grinsted for advice and discussions, and the Science Research Council for financial support.

\section{References}

Andrews, P. (1965) Biochem. J. 96, 595-606

Arrand, J. R., Myers, P. A. \& Roberts, R. J. (1978) J. Mol. Biol. 118, 127-135

Berg, D. E. (1977) in DNA Insertion Elements, Plasmids and Episomes (Bukhari, A. I., Shapiro, J. A. \& Adhya, S. L., eds.), pp. 555-558, Cold Spring Harbor Laboratory, Cold Spring Harbor

Bingham, A. \& Atkinson, A. (1978) Biochem. Soc. Trans. 6, 315-324

Bradford, M. M. (1976) Anal. Biochem. 72, 248-254

Chater, K. F. (1977) Nucleic Acids Res. 4, 1989-1998

Chater, K. F. \& Wilde, L. C. (1976) J. Bacteriol. 128, 644-650

Chater, K. F. \& Wilde, L. C. (1980) J. Gen. Microbiol. 116, 323-334

Clarke, C. M. \& Hartley, B. S. (1979) Biochem. J. 177, 49-62

Davis, B. J. (1964) Ann. N.Y. Acad. Sci. 121, 404-427

Greene, P. J., Heyneker, H. L., Bolivar, F., Rodriquez, R. L., Betlach, M. C., Covarrubias, A. A., Backman, K., Russel, D. S., Tait, R. \& Boyer, H. W. (1978) Nucleic Acids Res. 5, 2373-2380

Halford, S. E. (1971) Biochem. J. 125, 319-327

Halford, S. E. \& Johnson, N. P. (1981) Biochem. J. 199, 767-777

Halford, S. E., Johnson, N. P. \& Grinsted, J. (1979) Biochem. J. 179, 353-365

Johnson, P. H. \& Grossman, L. I. (1977) Biochemistry 16, 4217-4225

Jovin, T. M. (1976) Annu. Rev. Biochem. 45, 889-920

Laemmli, U. K. (1970) Nature (London) 227, 680-685

Maxwell, A. \& Halford, S. E. (1982a) Biochem. J. 203, 85-92

Maxwell, A. \& Halford, S. E. (1982b) Biochem. J. 203, 93-98

Modrich, P. (1979) Q. Rev. Biophys. 12, 315-369

Roberts, R. J. (1976) C.R.C. Crit. Rev. Biochem. 4, 123-164

Roberts, R. J. (1981) Nucleic Acids Res. 9, r75-r96 
Rodriguez, R. L., Bolivar, F., Goodman, H. M., Boyer, H. W. \& Betlach, M. (1976) in Molecular Mechanisms in the Control of Gene Expression (Nierlich, D. P., Rutter, W. J. \& Fox, C., eds.), pp. 471-477, Academic Press, New York
Sharp, R. A., Sugden, B. \& Sambrook, J. (1973) Biochemistry 12, 3055-3063

Smith, H. O. \& Wilcox, K. W. (1970) J. Mol. Biol. 51, 379-391

Smith, H. O. (1979) Science 205, 455-462 